\title{
Mediating migration
}

\section{Melis Mevsimler \& Sandra Ponzanesi}

To cite this article: Melis Mevsimler \& Sandra Ponzanesi (2017) Mediating migration, Feminist Media Studies, 17:4, 695-697, DOI: 10.1080/14680777.2017.1330998

To link to this article: https://doi.org/10.1080/14680777.2017.1330998

\section{曲 Published online: 07 Jun 2017.}

Submit your article to this journal

LII Article views: 29

Q View related articles $\widetilde{ }$

View Crossmark data $₫$ 
of Kink presents readers with an interdisciplinary, disruptive method to decode black female performance in a way that honors the agency in interpretation yet recognizes the structural constraints that limit such an interpretation. Additionally, her genealogy of discursive construction(s) around black female sexuality within kink—or "critical kink" (14)—offers theories, terminology, and perspectives that have the capacity to strengthen the work of scholarship beyond porn studies, including (but not limited to) practitioners of feminist media studies, critical race theory, and queer theory. In this way, Cruz offers us a critical lens with which to confidently consider the pleasure in taboo sexual performance, to contemplate the ways that BDSM performers "play" with race, to recognize the ways that commercial pornography "stabilizes" difference, and to honor the ways that the repetitive visibility of historical trauma has emancipatory potential.

\section{References}

Miller-Young, Mireille. 2014. A Taste for Brown Sugar:Black Women in Pornography. Durham, NC: Duke University Press. Nash, Jennifer C. 2014. The Black Body in Ecstasy: Reading Race, Reading Pornography. Durham, NC: Duke University Press.

Rachael A. Liberman

University of Denver

QRachael.Liberman@du.edu

(c) 2017 Rachael A. Liberman https://doi.org/10.1080/14680777.2017.1330996

Check for updates

Mediating migration, by Radha S. Hegde, Cambridge, UK, Polity Press, 2016, 161 pp. (paperback), ISBN-13: 978-0-7456-4633-6

In recent years, there has been a considerable increase in scholarly work on the intersections between media and migration. Mediating Migration contributes to this body of literature by engaging with the cultural politics of migration and its many forms of representation, elaborating on "the tension between the vertebrate structure of the nation and the cellular logic of flexible capital" (5). Hegde starts her book by referring to an interesting news story that speculates about an undocumented migrant who won mega-millions in a lottery in the United States. Journalistic accounts like this - and many other stories in the public media - constitute the backbone of this book, and each can be seen as a separate yet interlinked narrative about the relations between migration, communication technologies, and globalization. As the book demonstrates, the relationship between the media and migration is neither linear nor contained within the nationstate. Hegde approaches this relationship not only by analysing the media's power in shaping popular narratives and policies at the level of institutional structures, but also by focusing on migrants' participatory agency and dynamic engagement with various mediascapes. As Hegde states, "[t]he arguments and descriptions of this book cohere around the perspective that the subject of immigration and the debates around it have to be understood in terms of their transnational and cross-border implications" (4).

Hegde draws on several disciplinary backgrounds to elaborate on the relationship between media and migration, but her major focus is on reviewing non-media-centric approaches within the field of media and communications that allow transnational entanglements to be captured. In this regard, she draws on mediation theory and argues for contextualization by referring to 
well-known academics in the field such as Nick Couldry (2008), Lawrence Grossberg (1993), David Morley (2011), and Roger Silverstone (2002, 2005). Her alignment with non-media-centric approaches and her emphasis on contextualization is strengthened by her reference to Arjun Appadurai's widely cited work Modernity at Large (1996). By following Appadurai, she accentuates the need to establish conceptual and methodological trajectories that could help us to contextualize the transformative role that various social, economic, and cultural factors play in the era of globalization. The book illustrates the need to employ multiple analytical frameworks and disciplinary traditions to address this scholarly challenge.

Hegde's in-depth analysis of journalistic accounts and social media events reflects ongoing, mediated contestations over representation, legitimacy, and recognition in the public sphere. Hegde illustrates these contestations through particular cases in the United States. For example, Chapter 2 focuses on media activism and the mobilization of undocumented migrants in the United States. This chapter shows how newspapers and social media platforms are used as tools of resistance and mobilization by migrants who seek to challenge dominant narratives of citizenship. Although this chapter takes an optimistic tone regarding the use of new media technologies, Hegde also clearly cautions us by pointing to many other cases that offer a completely different picture. For instance, in Chapter 3 we see how the culture of surveillance and fear following the September 11 attacks promoted the idea that citizens can also use technology to counter terrorism. In such a context, social media platforms turn into virtual spaces where banal forms of nationalism and racism are perpetuated by the users. These two chapters show how media are embedded in different contestations of citizenship, reminding us that "[d]igital media are not technologies we merely use [...]. They become a constitutive part of the ways in which we sort the social world, recognize or misrecognize difference" (51).

The book also addresses intersections between media and migration by critically engaging with the notion of the public sphere and examining the underlying presumptions that guide normative understandings of effective communication (19). In Chapter 4, Hegde refers to postcolonial scholars such as Dipesh Chakrabarty (2000), Mahmood Mamdani (2005), and Timothy Mitchell (2000) in order to address how so-called cultural differences between the West and the Other are reproduced in media and public discourse around gender. The book not only deals with the issue of gender by analysing dominant public and media discourses about the gendered migrant subject, it also looks at the ways migrant women use media, and digital media in particular, in order to build their own transnational connections and to reimagine diasporic identities (69). In this regard, the book contributes to the existing literature that challenges territorially bounded understandings of media consumption (e.g., Myria Georgiou 2006; Marie Gillespie 1995; Roza Tsagarousianou 2004) with its specific focus on gender. This contribution comes in Chapter 5 , which presents Hegde's small-scale study of South Asian migrant women who have food/culinary blogs. Unlike previous chapters, this chapter draws on interviews and analysis of the blogs, with the aim of examining women's blogging practices "as an evolving visual and textual archive about Indian food and the diasporic everyday experience" (71). This particular case illustrates one of the major strengths of Hegde's book, which is its situation of the everyday practices of diasporic subjects within the global neoliberal context. By unpacking the neoliberal underpinnings of digital media, Hegde undoubtedly invites us to rethink the connections between (gendered) everyday lives and the global marketplace where social hierarchies are reproduced and reinforced online via algorithms and interfaces.

Mediating Migration is a particularly good guide for those who seek to understand how the theories and concepts of media and communications can be reworked transnationally beyond the contextual logics of the nation by addressing how the intersection of technologies, economies, and borders operates in mediating migration. While the book does not limit itself to a single conceptual or methodological trajectory, it offers scholars a wide range of tools and critical ways of thinking that will help them examine the power and pitfalls of global mediascapes. 


\section{References}

Appadurai, Arjun. 1996. Modernity at Large: Cultural Dimensions of Globalization. Minneapolis: University of Minnesota Press.

Chakrabarty, Dipesh. 2000. Provincializing Europe: Postcolonial Thought and Historical Difference. Princeton, NJ: Princeton University Press.

Couldry, Nick. 2008. "Mediatization or Mediation? Alternative Understandings of the Emergent Space of Digital Storytelling." New Media and Society 10 (3): 373-391.

Georgiou, Myria. 2006. Diaspora, Identity and the Media:Diasporic Transnationalism and Mediated Spatialities. Cresskill: Hampton Press.

Gillespie, Marie. 1995. Television, Ethnicity and Cultural Change. London: Routledge.

Grossberg, Lawrence. 1993. "Can Cultural Studies Find True Happiness in Communication?" Journal of Communication 43 (4): 87-97.

Mamdani, Mahmood. 2005. Good Muslim, Bad Muslim: America, the Cold War, and the Roots of Terror. New York, NY: Harmony.

Mitchell, Timothy. 2000. "Introduction." In Questions of Modernity, edited by T. Mitchell, xi-xxii. Minneapolis: University of Minnesota Press.

Morley, David. 2011. "Communications and Transport: The Mobility of Information, People and Commodities." Media, Culture \& Society 33 (5): 743-759.

Silverstone, Roger. 2002. "Complicity and Collusion in the Mediation of Everyday Life." New Literary History 33 (4): 761-780.

Silverstone, Roger. 2005. "The Sociology of Mediation and Communication." In The Sage Handbook of Sociology, edited by Craig Calhoun, Chris Rojek, and Bryan S. Turner, 188-207. Thousand Oaks, CA: Sage.

Tsagarousianou, Roza. 2004. "Rethinking the Concept of Diaspora: Mobility, Connectivity and Communication in a Globalized World." Westminster Paper in Communication and Culture 1 (1): 52-66.

Melis Mevsimler and Sandra Ponzanesi Utrecht University

@m.mevsimler@uu.nl and s.ponzanesi@uu.nl

(c) 2017 Melis Mevsimler and Sandra Ponzanesi https://doi.org/10.1080/14680777.2017.1330998

Check for updates

\section{Teaching transnational cinema: politics and pedagogy, edited by Katarzyna}

Marciniak and Bruce Bennett, London, Routledge, 2016, 311 pp. (hardback), ISBN-13:

\section{8-1138928435}

The transnational turn has steadily become one of the liveliest and politically most urgent paradigms in the current landscape of film and media studies, one particularly susceptible to a variety of feminist approaches. Taking as its starting point the fact that exile, diaspora, migration, and displacement are lived experiences of an increasing number of people in our globalized present, the framework of transnational cinema arguably engages transnational feminist politics by default, through its insistence on examining the crosslinks between the nation, location, and identity, including the vicissitudes of gender and sex in an era defined by the uneven globalizing flows of power/knowledge. In 1994, Inderpal Grewal and Caren Kaplan argued that "without an analysis of transnational scattered hegemonies that reveal themselves in gender relations, feminist movements will remain isolated and prone to reproducing the universalizing gestures of dominant Western cultures" (17). The same can be said of transnational cinema as a praxis of political struggle. Transnational cinema presents a critical domain where scattered hegemonies are illuminated and reflected, oftentimes through a feminist lens.

The volume at hand is a significant addition to the growing body of work on transnational cinema, and moreover, one that brings critical pedagogy into the equation. Pedagogy is of particular 